\title{
The patients' organisations of children with primary immunodeficiency in Poland
}

\author{
Ewa Bernatowska ${ }^{1 *}$, Malgorzata Pac $^{1}$, Dorota Marynowicz ${ }^{2}$ \\ From 5th European Conference on Rare Diseases (ECRD 2010) \\ Krakow, Poland. 13-15 May 2010
}

Primary immunodeficiency are rare diseases, approximately 1 per 10000 children are affected. Since 1980, the Department of Immunology at the Childrens' Memorial Health Institute (CMHI) is the reference centre for PIDs for the whole of Poland. Up to now, 1,098 children with PID have been diagnosed. Since 2010, the Department of Immunology CMHI has been nominated as a Jeffrey Modell Foundation Diagnostic Centre. Thanks to the initiative of the Department of Immunology the first patients' organisation named the Association of Friends for Children with Immunological System Deficiencies was founded in 1987. The original members are patients and their families and friends, doctors, nurses and other medical staff. The Association co-operated with similar organisations such as ESID, IPOPI, INGID up to 1999, when they finished their activity. The other patients' organisations have been founded, which focused on specific immune diseases (e.g. for DiGeorge syndrome, Nijmegen Breakage Syndrome etc.). These organisations are small and not very active, besides Ataxia-Telangiectasia Foundation which collected large group of patients with AT. In 2007, a new patients' organisation named IMMUNOPROTECT was set up which gathered parents of patients with primary antibody deficiencies mainly. The main aim of setting up this unit has encompassed the support of children and adults with primary immuno-deficiencies. Basic activity comprises development of an educational programme for patients and families with primary immuno-deficiencies and information initiatives for doctors and parents concerning primary immunodeficiency disorders. IMMUNOPROTECT started to put together other small groups of patients as a reasonable way to build up one powerful, effective

\footnotetext{
*Correspondence: bernatowskae@yahoo.com

${ }^{1}$ Children Memorial Health Institute, av.Dzieci Polskich 20, 04-730 Warsaw, Poland

Full list of author information is available at the end of the article
}

organisation. These organisations aim at providing better care and access to sufficient treatment.

\section{Author details}

${ }^{1}$ Children Memorial Health Institute, av.Dzieci Polskich 20, 04-730 Warsaw, Poland. ${ }^{2}$ Immunoprotect, Okręgowa 64, 93-367 Łódź, Poland.

Published: 19 October 2010

doi:10.1186/1750-1172-5-S1-P24

Cite this article as: Bernatowska et al:: The patients' organisations of children with primary immunodeficiency in Poland. Orphanet Journal of Rare Diseases 2010 5(Suppl 1):P24.
Submit your next manuscript to BioMed Central and take full advantage of:

- Convenient online submission

- Thorough peer review

- No space constraints or color figure charges

- Immediate publication on acceptance

- Inclusion in PubMed, CAS, Scopus and Google Scholar

- Research which is freely available for redistribution

Submit your manuscript at www.biomedcentral.com/submit
Biomed Central 